\title{
EFEK PIJAT KAKI TERHADAP KUALITAS TIDUR IBU MENOPAUSE
}

\author{
Rahmi Nurrasyidah* \\ *Dosen Jurusan Kebidanan Poltekkes Kemenkes Surakarta Jawa Tengah \\ email: rahmi.nurrasyidah@gmail.com
}

\begin{abstract}
Background : Sleep disturbance is a problem that is often complained of by women who experience a menopause transition. This has an impact on quality of life, moods, productivity, and physical health. Foot massage therapy is a non-pharmacological therapy performed to improve sleep quality. Non-pharmacological therapy is an option because it is cheaper and more effective when compared with medical administration.

Purpose :This study determined an effect of foot massage on the sleep quality of menopausal mothers.

Method: This is an experimental study with a post test only control group design. The sample consisted of 23 respondents aged 45-55 years. The intervention group included 12 respondents and the control group included 11 respondents. The intervention group performed foot massage for 10 minutes on each leg. Sleep quality in the intervention group was measured 24 hours after massage. The control group did not do foot massage.

Results : the average respondent of intervention and control groups were in the best sleep quality (76100). In the control group, poor sleep quality was found in the wakefulness sleep category. There was no difference in the average quality of sleep in mothers who did foot massage and did not do foot massage ( $p>$ 0.001) with a difference in average $(95 \% \mathrm{Cl}) 4.5$ (3.6-12.5).

Conclusion: There was no difference in the average quality of sleep between intervention and control group.

Sugestion : Based on the results of the study, the authors recommend the need for further research on foot massage with an increase in duration of the intervention and it is necessary to investigate the variations of foot massage methods with aromatherapy to improve sleep quality. Further research needs to be done with more samples and better RCT methods.
\end{abstract}

Keywords: Foot massage, sleep quality, Menopause

\section{ABSTRAK}

Latar Belakang: Gangguan tidur adalah masalah yang sering dikeluhkan ibu yang mengalami transisi menopause. Hal ini berdampak pada kualitas hidup, suasana hati, produktivitas, dan kesehatan fisik. Terapi pijat kaki merupakan terapi non farmakologi yang dilakukan untuk meningkatkan kualitas tidur. Terapi non-farmakologi menjadi pilihan karena biaya yang lebih murah dan lebih efektif bila dibandingkan dengan pemberian medikamentosa.

Tujuan : Untuk mengetahui pengaruh pijat kaki terhadap kualitas tidur ibu menopause.

Metode : Desain Penelitian ini adalah penelitian eksperimental dengan desain post test only control group desain. Sampel terdiri dari 23 responden yang berumur 45-55 tahun dengan rincian kelompok intervensi 12 responden dan kelompok kontrol 11 responden. Kelompok intervensi dilakukan pijat kaki selama 10 menit pada setiap kaki. Kualitas tidur pada kelompok intervensi diukur 24 jam setelah dilakukan pemijatan. Kelompok kontrol tidak dilakukan pijat kaki.

Hasil : Rata-rata responden pada kelompok intervensi maupun kontrol berada pada kualitas tidur terbaik (76-100). Pada kelompok kontrol, didapatkan kualitas tidur yang buruk pada kategori terbangun saat tidur (Awakenings). Tidak terdapat perbedaan rerata kualitas tidur pada ibu yang dilakukan pijat kaki dan tidak dilakukan pijat kaki $(p>0,001)$ dengan perbedaan rerata (IK 95\%) 4.5 (3.6-12.5).

Kesimpulan : Tidak terdapat perbedaan rerata kualitas tidur pada kelompok intervensi maupun kontrol. .

Saran : Penulis merekomendasikan perlunya dilakukan penelitian lebih lanjut mengenai pijat kaki dengan peningkatan durasi intervensi serta perlu diteliti mengenai variasi metoda pijat kaki dengan aromaterapi untuk meningkatkan kualitas tidur. Penelitian selanjutnya perlu dilakukan dengan sampel yang lebih banyak dengan metode uji kilnis yang lebih baik.

Kata Kunci : Pijat kaki, kualitas tidur, Ibu Menopause 


\section{PENDAHULUAN}

Menopause adalah masa berhenti menstruasi pada wanita. Terdapat masa transisi sebelum menstruasi berhenti. Masa transisi ini dimulai 4-6 tahun sebelum menstruasi berhenti. Biasanya terjadi pada usia rata-rata 51 tahun. Masa pramenopause berhubungan dengan berfluktuasinya kadar hormon dan munculnya gejala fisiologis dan psikologis seperti hot flash, gangguan tidur, perubahan suasana hati, dan kekeringan pada vagina. Gejala pramenopause pada wanita dapat bervariasi dalam hal frekuensi, keparahan, dan durasi. Pada beberapa wanita, gejala ini bertahan selama beberapa tahun setelah menopause. Gangguan tidur adalah keluhan utama wanita yang mengalami transisi menopause. Hal ini berdampak pada kualitas hidup, suasana hati, produktivitas, dan kesehatan fisik, terutama pada wanita yang mengalami gangguan tidur yang parah dan terkait dengan gangguan fungsi tubuh. (Baker, F. C., De Zambotti, M., Colrain, I. M., \& Bei, B, 2018)

Penyebab sulit tidur adalah rendahnya kadar serotin pada ibu pre menopause. Kadar serotin dipengaruhi oleh kadar endorfin. Gangguan tidur yang paling sering ditemukan adalah insomnia. Dilaporkan bahwa sekitar $20 \%-50 \%$ orang dewasa mengalami gangguan tidur setiap tahunnya dan sekitar $17 \%$ mengalami gangguan tidur yang serius. Sekitar $67 \%$ lansia mengalami gangguan tidur. Mayoritas lansia tidak memeriksakan masalah gangguan tidur pada dokter. Hanya satu dari delapan kasus yang menyatakan bahwa gangguan tidurnya telah didiagnosis oleh dokter. (Achadiat, C. M. , 2007)

Kejadian insomnia meningkat lebih cepat pada ibu dengan umur di atas 40 tahun. Sekitar 40\% wanita usia 40-54 tahun mengeluh insomnia, hanya $20 \%$ pria pada kelompok usia yang sama yang mengeluh insomnia. Kesulitan tidur mencapai puncaknya pada kelompok usia 65-69 tahun, dialami sekitar $40 \%$ wanita dan $25 \%$ pria. Wanita 1,5 kali lebih sering mengidap insomnia dibandingkan pria, dan 20-40\% lansia mengeluhkan gejala-gejala insomnia tiap beberapa hari dalam 1 bulan. Wanita menunjukkan prevalensi insomnia lebih sering dibanding pria disebabkan terjadinya menopause yang berhubungan dengan menurunnya kadar estrogen pada wanita menopause. Insomnia kronis ditemukan pada wanita yang mengalami menopause dan hal ini berkorelasi dengan timbulnya hot flush yang merupakan sensasi panas disertai keringat. Hal ini mengakibatkan ibu tidak dapat beraktifitas. (Gunadarma, R. S. P. , 2016)
Pendekatan terapi pada penderita insomnia ini dapat dilakukan secara farmakologis atau nonfarmakologis, berdasarkan berat dan perjalanan gejala insomnia itu sendiri. Pada dasarnya, penanganan dengan obat-obatan bisa dilakukan dengan benzodiazepine, non-benzodiazepine dan miscellaneous sleep promoting agent. Penanganan non farmakologi insomnia dapat berupa stimulus control, sleep restriction, sleep higiene dan cognitive therapy. Berdasarkan penelitian, terapi non-farmakologi menjadi pilihan karena biaya yang lebih murah dan lebih efektif bila dibandingkan dengan pemberian medikamentosa. (Ghaddafi, M, 2010)

Terapi pijat kaki merupakan terapi non farmakologi yang telah banyak dilakukan untuk meningkatkan kualitas tidur. Berdasarkan metaanalisis yang dilakukan oleh Yang, H. J., Kang, H. Y., \& Kim, I. S. (2011) terdapat 18 penelitian yang meneliti mengenai terapi pijat refleksi kaki terhadap kualitas tidur. Berdasarkan metaanalisis tersebut, pijat refleksi pada kaki dapat meningkatkan kualitas tidur.

Terapi pijat kaki pada ibu menopause masih belum banyak diteliti. Berdasarkan latar belakang di atas, penulis tertarik untuk meneliti "Efek Pijat Kaki terhadap Kualitas Tidur Ibu Menopause"

\section{METODE PENELITIAN}

Penelitian ini merupakan penelitian eksperimental dengan desain post test only control group. Kelompok intervensi diberikan pijat kaki selama 10 menit pada kaki kiri dan kanan. Kualitas tidur diukur sesudah 24 jam dilakukan intervensi. Kelompok kontrol tidak dilakukan intervensi apapun. Penelitian dilakukan di Dukuh Daleman, Sidomulyo Ampel, Boyolali pada bulan Desember 2019. Sampel yang dipakai dalam penelitian ini adalah 23 responden yang berumur 45-58 tahun. Teknik pengambilan sampel dilakukan dengan simple random sampling. Kriteria ekslusi dari penelitian ini adalah ibu menopause dengan gangguan kesadaran, gangguan mental, terdapat cedera kaki dan gangguan pembekuan darah. Kelompok intervensi 12 responden dan kelompok kontrol 11 responden. Pengumpulan data dilakukan dengan menggunakan data primer yang didapatkan melalui intervensi pijat kaki dan kuesioner kualitas tidur pada ibu menopause. Intrumen kualitas tidur menggunakan alat pengukur RSCQ (Richard Campbell Sleep Questionnaire). Sebelum dilakukan pemijatan, kaki terlebih dahulu dibersihkan dengan sabun dan air mengalir. Pijat kaki dilakukan dengan menggunakan minyak zaitun, pijat kaki dilakukan selama 10 menit. Seluruh permukaan kaki dipijat 
dari tumit sampai jari-jari dengan kedua tangan menggunakan teknik efflurage. Pijat sela jari kaki dengan teknik spiral, pijat tumit kaki dengan genggaman tangan ke arah bawah. Lakukan pijatan akupressure pada titik K1. Analisis data menggunakan Uji T Tidak Berpasangan

\section{HASIL PENELITIAN}

Analisa Univariat

Distribusi Frekuensi Karakteristik Responden
Tabel 1. Distribusi Frekuensi Karakteristik Responden

\begin{tabular}{ccc}
\hline Umur & frekuensi & Presentase $(\%)$ \\
\hline $45-55$ & 18 & 78,3 \\
$56-58$ & 5 & 21,7 \\
\hline Jumlah & 23 & 100 \\
\hline
\end{tabular}

Tabel 1 menunjukkan bahwa sebagian besar responen $(78,3 \%)$ berusia $45-55$ tahun.

Rata-rata kualitas tidur responden pada 2 kelompok

Tabel 2.

Tabel Rata-Rata Kualitas Tidur Responden Pada Dua Kelompok

\begin{tabular}{lcccc}
\hline \multirow{2}{*}{ Kualitas Tidur } & \multicolumn{2}{c}{ Intervensi } & \multicolumn{2}{c}{ Kontrol } \\
\cline { 2 - 5 } & Mean & $\mathrm{n}$ & Mean & $\mathrm{n}$ \\
\hline Tidur nyenyak (Sleep depth) & 86.3 & 12 & 78.2 & 11 \\
Persiapan tidur (Sleep latency) & 83.8 & 12 & 82 & 11 \\
Terbangun saat tidur (Awakenings) & 84.6 & 12 & 75 & 11 \\
Kembali tidur (Returning to sleep) & 81.7 & 12 & 79.6 & 11 \\
Kualitas tidur (Sleep quality) & 83.3 & 12 & 84.1 & 11 \\
\hline
\end{tabular}

Berdasarkan tabel di atas, diketahui bahwa rata-rata responden pada kelompok intervensi maupun kontrol berada pada kualitas tidur terbaik (76-100). Pada kelompok kontrol, didapatkan kualitas tidur yang buruk pada kategori terbangun saat tidur (Awakenings)

\section{Analisis Bivariat}

Pengaruh Pijat Kaki Pada Ibu Menopause

Tabel 3.

Pengaruh Pijat Kaki Pada Ibu Menopause

\begin{tabular}{|c|c|c|c|c|}
\hline Variabel & $n$ & $\begin{array}{c}\text { Rerata } \pm \\
\text { sb. }\end{array}$ & $\begin{array}{c}\text { Perbedaan } \\
\text { Rerata } \\
\text { (IK95\%) }\end{array}$ & $P$ \\
\hline Pijat ka & 12 & $83.9 \pm 7.8$ & \multirow{2}{*}{$\begin{array}{c}4.5(3.6- \\
12.5)\end{array}$} & \multirow[b]{2}{*}{$>0,001$} \\
\hline $\begin{array}{l}\text { Tidak } \\
\text { pijat kaki }\end{array}$ & 11 & $71 \pm 13.1$ & & \\
\hline
\end{tabular}

Uji T Tidak Berpasangan

Berdasarkan tabel 3 dapat diambil kesimpulan bahwa tidak terdapat perbedaan rerata kualitas tidur pada ibu yang dilakukan pijat kaki dan tidak dilakukan pijat kaki.

\section{PEMBAHASAN}

Hasil penelitian menunjukkan bahwa sebagian besar responden $(78,3 \%)$ berusia $45-55$ tahun. Menurut Harlow, S. D., Gass, M., Hall, J. E., Lobo, R., Maki, P., Rebar, R. W (2012) menopause terjadi pada rentang usia 50 sampai 58 tahun. Masa ini merupakan masa yang sangat kompleks bagi perempuan karena akan mengalami perubahan kesehatan fisik yang akan mempengaruhi kesehatan psikologisnya. Akibat dari perubahan ini, keadaan fisik seorang perempuan sangat mempengaruhi keadaan psikologisnya dalam mengahadapi hal normal sebagaimana yang dialami oleh semua perempuan.

Pra menopause adalah kondisi fisiologis pada wanita yang telah memasuki proses penuaan (aging). Hal ini terjadi karena menurunnya kadar hormon estrogen di ovarium yang sangat berperan dalam hal seksualitas, khususnya pada siklus haidnya. Pre menopause sering dialami wanita yang berusia menjelang 40 tahun ke atas dan menimbulkan gejala-gejala seperti perdarahan haid yang memanjang, hot flushes, night sweat, jumlah darah haid yang banyak dan merasakan nyeri saat haid (Rossmanith, W. G., \& Ruebberdt, W., 2009)

Dalam penelitian ini, rata-rata responden pada kelompok intervensi maupun kontrol berada pada kualitas tidur terbaik (76-100). Hal ini dapat terjadi karena rata-rata responden telah melewati masa Hot Flash dan tidak mengalami depresi. Menurut Smith, R. L., Flaws, J. A., \& Mahoney, M. M (2018) Tidur yang buruk dalam satu tahap menopause tidak memprediksi tidur yang buruk di masa menopause selanjutnya. Depresi dan hot flash adalah faktor risiko yang konsisten untuk kurang tidur saat menopause. Insomnia, gangguan 
tidur, dan tidur gelisah biasanya terjadi bersamaan.

Pada kelompok kontrol, didapatkan kualitas tidur yang buruk pada kategori terbangun saat tidur (Awakenings). Menurut Cray, L., Woods, N. F., \& Mitchell, E. S (2010) Tingkat keparahan terbangun di malam hari secara signifikan terkait dengan usia, tahap transisi menopause akhir, hot flash, suasana hati tertekan, kecemasan, nyeri sendi, sakit punggung, stres yang dirasakan, dan riwayat pelecehan seksual.

Gejala terbangun dari tidur ada kaitannya dengan asupan nutrisi dan aktivitas fisik ibu menopause. Berdasarkan hasil penelitian Koeryaman, M. T., \& Ermiati, E. (2018) mengenai kualitas hidup ibu menopause, adaptasi gejala perimenopause didominasi pada kategori penanganan tidak baik. Sebagian besar ibu menopause menunjukkan gambaran pengaturan nutrisi tidak baik sebesar $58,13 \%$. Hal tersebut menunjukkan bahwa para ibu menopause tidak mengatur asupan nutrisi yang seimbang. Data lainnya menunjukkan bahwa para ibu menopause masih sering mengkonsumsi kopi, makanan pedas, dan merokok.

Gangguan tidur pada ibu menopause dapat menyebabkan penurunan kualitas hidup. Ditemukan perbedaan pada domain fisik dan lingkungan pada ibu menopause dengan gejala yang ringan dan parah. Ibu dengan gejala menopause parah mengaku lebih sering merasa sakitnya menghambat aktivitas, kurang cukup memiliki vitalitas, kurang puas dengan kualitas tidur mereka, serta kurang puas terhadap kemampuan bekerja dan beraktivitas sehari-hari. Hal tersebut kemungkinan dapat dikaitkan juga dengan gejala menopause seperti sering mengalami kelelahan fisik dan sakit pada persendian. Daya ingat menurun lebih sering dialami oleh mereka. Mereka juga mengakui kurang memiliki kesempatan untuk berekreasi dan kurang puas terhadap akses layanan kesehatan dan akses transportasi. (Putri, D. I., Wati, D. M., \& Ariyanto, Y, 2014)

Berdasarkan penelitian ini, tidak terdapat perbedaan rerata kualitas tidur pada ibu yang dilakukan pijat kaki dan tidak dilkukan pijat kaki. Hasil penelitian ini bertentangan dengan penelitian sebelumnya tentang peningkatan kualitas tidur setelah dilakukan pijat kaki. Perbedaan ini disebabkan oleh perbedaan lama intervensi pada responden. Pada penelitian ini, intervensi hanya dilakukan sehari selama 10 menit pada tiap kaki. Pada penelitian yang lain, intervensi dilakukan dua hari berturut turut selama 10 menit pada tiap kaki.

Pada suatu penelitian tentang pijat kaki di ICU, skor kualitas tidur pada kelompok intervensi lebih tinggi daripada kelompok kontrol, sehingga disarankan foot massage dijadikan evidence based di rumah sakit sebagai salah satu terapi komplementer yang dapat dijadikan intervensi mandiri keperawatan untuk membantu mengatasi gangguan tidur pasien kritis. Pijat kaki dilakukan 2 hari berturut-turut setiap 10 menit pada satu kaki (Afianti, N., \& Mardhiyah, A. 2017)

Pada penelitian yang lain, pijat kaki dilakukan selama 20 menit dalam 2 hari berturutturut. Menurut Oshvandi, K., Abdi, S., Karampourian, A., Moghimbaghi, A., \& Homayounfar, S (2014) pijat kaki yang dilakukan 20 menit dalam dua malam berturut-turut dapat meningkatkan kualitas tidur pada pasien jantung. Pijat kaki dapat digunakan sebagai terapi yang efektif dengan biaya yang murah, tidak menyebabkan komplikasi. Selain itu, prosedur pijat kaki juga mudah. Pijat kaki dapat dianjurkan untuk meningkatkan kualitas tidur pada pasien dengan penyakit jantung iskemik.

Pada penelitian selanjutnya, perlu dipertimbangkan penggunaan aromaterapi untuk meningkatkan efek kualitas tidur pada pijat kaki. Menurut penelitian Yang, H. J., Kang, H. Y., \& Kim, I. S. (2011) Aroma pijat kaki bisa digunakan sebagai intervensi yang efektif untuk meningkatkan kualitas tidur dan menurunkan depresi lansia dengan demensia ringan. Intervensi dilakukan 2 kali seminggu, selama 6 minggu.

Berdasarkan penelitian Frenando, F. (2018) yang melakukan analisis pengaruh aromaterapi lavender dan kayu cendana terhadap kondisi tidur seseorang. Kondisi tidur direkam menggunakan EEG saat tidur dan dianalisis sinyal otaknya. Temuan EEG menunjukkan perubahan kondisi tidur dari rileks (alpha) pada bagian 1, tidur ringan (theta) pada bagian 2 dan tidur dalam (delta) pada bagian 3. Kesimpulan penelitian tersebut menunjukkan bahwa penggunaan aromaterapi lavender dan kayu cendana memberikan pengaruh terhadap kenyamanan saat tidur.

Penelitian aromaterapi juga diteliti oleh Fauziah E (2018) minyak esensial aromaterapi kenanga yang dihirup oleh lansia merupakan terapi pengobatan alternatif praktis dalam meningkatkan derajat kualitas tidur.

\section{KESIMPULAN}

Berdasarkan hasil penelitian diketahui bahwa rata-rata responden pada kelompok intervensi maupun kontrol berada pada kualitas tidur terbaik. Pada kelompok kontrol, didapatkan kualitas tidur yang buruk pada kategori terbangun saat tidur (Awakenings). Tidak terdapat perbedaan 
rerata kualitas tidur pada ibu yang dilakukan pijat kaki dan tidak dilakukan pijat kaki.

\section{SARAN}

Penulis merekomendasikan perlunya dilakukan penelitian lebih lanjut mengenai pijat kaki dengan peningkatan durasi intervensi serta perlu diteliti mengenai variasi metoda pijat kaki dengan aromaterapi untuk meningkatkan kualitas tidur. Penelitian juga perlu dilakukan dengan sampel yang lebih banyak dengan metode uji kilnis yang lebih baik.

\section{DAFTAR PUSTAKA}

Achadiat, C. M. (2007). Dinamika etika \& hukum kedokteran dalam tantangan zaman. EGC.

Afianti, N., \& Mardhiyah, A. (2017). Pengaruh Foot Massage terhadap Kualitas Tidur Pasien di Ruang ICU. Jurnal Keperawatan Padjadjaran, 5(1).

Baker, F. C., De Zambotti, M., Colrain, I. M., \& Bei, B. (2018). Sleep problems during the menopausal transition: prevalence, impact, and management challenges. Nature and science of sleep, 10, 73 .

Cray, L., Woods, N. F., \& Mitchell, E. S. (2010). Symptom clusters during the late menopausal transition stage: observations from the Seattle Midlife Women's Health Study. Menopause, 17(5), 972-977.

Koeryaman, M. T., \& Ermiati, E. (2018). Adaptasi gejala perimenopause dan pemenuhan kebutuhan seksual wanita usia $50-60$ tahun. Medisains, 16(1), 21-30.

Fauziah, E. (2018). Pengaruh Pemberian Minyak Esensial Aromaterapi Kenanga Terhadap Kualitas Tidur Lansia Di Dusun Karang Tengah Nogotirto Gamping Sleman Yogyakarta.

Frenando, F. (2018). Ekstraksi Sinyal EEG Menggunakan Wavelet dan Fast Fourier Transform Untuk Mendeteksi Kondisi Tidur Dengan Stimulus Aromaterapi (Doctoral dissertation, Universitas Kristen Maranatha).

Ghaddafi, M. (2010). Tatalaksana Insomnia dengan Farmakologi atau Non-Farmakologi. E-Jurnal
Medika Udayana, 4, 1-17.

Gunadarma, R. S. P. (2016). Perbedaan Tingkat Insomnia Pada Wanita Pramenopaus Dan Menopause Di Perumahan Jetis Permai Gentan Baki Sukoharjo (Doctoral dissertation, Universitas Muhammadiyah Surakarta).

Harlow, S. D., Gass, M., Hall, J. E., Lobo, R., Maki, P., Rebar, R. W., ... \& STRAW+ 10 Collaborative Group. (2012). Executive summary of the Stages of Reproductive Aging Workshop+ 10: addressing the unfinished agenda of staging reproductive aging. The Journal of Clinical Endocrinology \& Metabolism, 97(4), 1159-1168.

Yang, H. J., Kang, H. Y., \& Kim, I. S. (2011). The effects of aroma foot reflex massage on sleep, depression and problem behaviors on elderly with dementia. Korean Journal of Adult Nursing, 23(6), 574-583.

Park, J. W., Yoo, H. R., \& Lee, H. S. (2006). The effects of foot reflex zone massage on patients pain and sleep satisfaction following mastectomy. Journal of Korean Academic Society of Home Health Care Nursing, 13(1), 54-60.

Oshvandi, K., ABDI, S., Karampourian, A., Moghimbaghi, A., \& HOMAYOUNFAR, S. (2014). The effect of foot massage on quality of sleep in ischemic heart disease patients hospitalized in CCU.

Putri, D. I., Wati, D. M., \& Ariyanto, Y. (2014). Kualitas hidup wanita menopause (quality of life among menopausal women). Pustaka Kesehatan, 2(1), 167-174.

Smith, R. L., Flaws, J. A., \& Mahoney, M. M. (2018). Factors associated with poor sleep during menopause: results from the Midlife Women's Health Study. Sleep medicine, 45, 98-105.

Rossmanith, W. G., \& Ruebberdt, W. (2009). What causes hot flushes? The neuroendocrine origin of vasomotor symptoms in the menopause. Gynecological Endocrinology, 25(5), 303-314. 